\title{
Fish Bone Penetrating into the Head of Pancreas in a Patient with Billroth II Gastrojejunostomy
}

\author{
Tan Attila Zeynel Mungan \\ Division of Gastroenterology and Hepatology, Koc University School of Medicine, Istanbul, Turkey; \\ Division of Gastroenterology and Hepatology, American Hospital, Istanbul, Turkey
}

Keywords

Pancreas · Endoscopy · Foreign body

\section{Espinha de Peixe a Penetrar na Cabeça do Pâncreas num Doente com Gastrojejunostomia do Tipo Bilroth II}

\section{Palavras Chave}

Pâncreas · Endoscopia · Corpo estranho

A 76-year-old male patient with a history of abdominal aortic aneurysm repair and Billroth II gastrojejunostomy (25 years ago) for refractory peptic ulcer disease presented with gradually worsening epigastric pain over the past $48 \mathrm{~h}$, without any associated fever. Physical examination was significant for epigastric discomfort. A complete blood count, liver function tests, and C-reactive protein were within normal limits. Pancreatic enzyme levels were not available. The day after admission, an upper endoscopy (GIF H260; Olympus, Tokyo, Japan) revealed changes consistent with Billroth II gastrojejunostomy. The gas-

\section{KARGER}

E-Mail karger@karger.com www.karger.com/pjg (c) 2018 Sociedade Portuguesa de Gastrenterologia Published by S. Karger AG, Basel

Karger

Upen access

This article is licensed under the Creative Commons Attribution NonCommercial-NoDerivatives 4.0 International License (CC BYNC-ND) (http://www.karger.com/Services/OpenAccessLicense). Usage and distribution for commercial purposes as well as any distribution of modified material requires written permission. tric remnant, distal afferent loop, and efferent loop mucosa appeared normal. An abdominal computerized tomography demonstrated a radiopaque foreign body penetrating into the pancreatic head, with the proximal portion partially residing in the duodenal lumen (Fig. 1). The patient acknowledged eating turbot fish 2 days prior to the onset of abdominal pain. In an attempt for endoscopic removal of the foreign body, the afferent enteral loop was deeply intubated with a therapeutic upper endoscope (GIF 2T 240; Olympus). The foreign body penetrating the duodenal wall (Fig. 2) was noted at the duodenal stump. The distal end of the fish bone was captured with a polypectomy snare and was removed in 1 piece. The snare's plastic sheath was left $2-3 \mathrm{~cm}$ distal to the tip of the endoscope to allow alignment of the fish bone's long axis with the axis of the lumen and the endoscope. Since the appropriate alignment was successfully achieved, an overtubeovertube was not used. The fish bone was removed from the lower and upper esophageal sphincters without any mucosal penetration and damage. The removed foreign body was $3.5 \mathrm{~cm}$ in length and consistent with a turbot bone (Fig. 3). The patient's pain improved following removal of the fish bone penetrating the head of pancreas. 


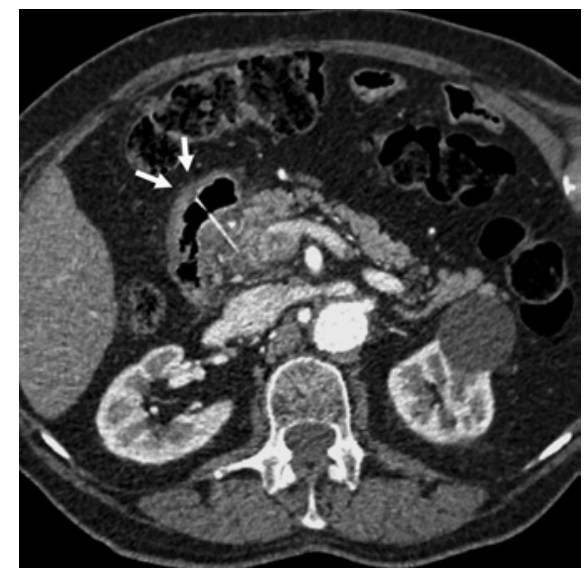

Fig. 1. Abdominal tomography revealing a radiopaque foreign body penetrating into the pancreatic head.

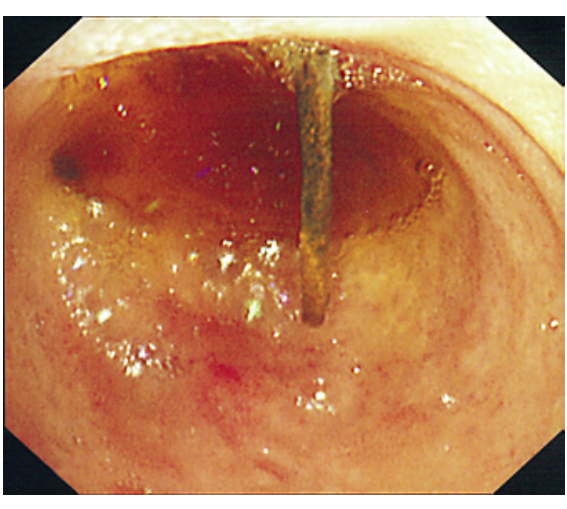

Fig. 2. Endoscopic examination revealing a foreign body penetrating the duodenal wall of the duodenal stump.

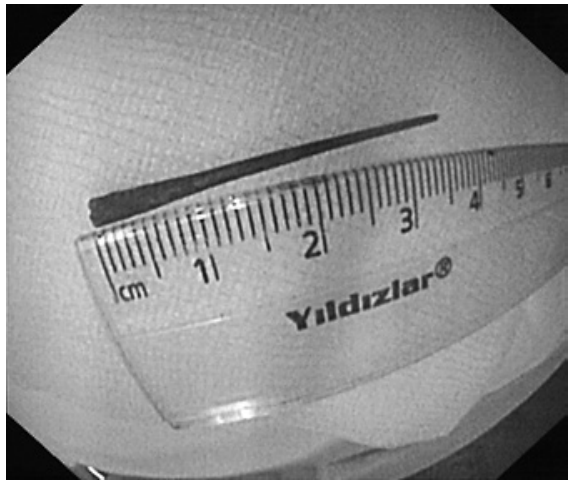

Fig. 3. The removed foreign body measures $3.5 \mathrm{~cm}$ in length and is consistent with a turbot bone.
Foreign body ingestion occurs commonly. The majority of foreign bodies pass through the gastrointestinal tract spontaneously. Rarely, ingestion of a sharp-pointed object such as a fish bone may potentially pierce the gastrointestinal wall and cause complications such as abscess formation in adjacent structures [1-3]. Patients are usually unable to provide a clear history of fish bone ingestion. Imaging may provide valuable information, especially in patients with a surgically altered anatomy as in our case. Early recognition may allow endoscopic removal of the penetrated fish bone in 1 piece and prevent further complications that may require surgical interventions. This case is unique because a fish bone migration in retrograde fashion into the afferent loop of Billroth II surgery and penetration into the pancreas through the duodenal stump has not previously been reported. It is extremely important to have an alignment of long, pointed objects with the axis of the lumen and endoscope to avoid iatrogenic mucosal damage and foreign body penetration into the gastrointestinal wall. If needed, an overtube or soft latex protector hood should be used to prevent iatrogenic injury during the removal of a foreign body.

\section{Statement of Ethics}

This study did not require informed consent or review/approval by the appropriate ethics committee.

\section{Disclosure Statement}

The authors have no conflicts of interest to declare.

References

1 Horii K, Yamazaki O, Matsuyama M, et al: Successful treatment of a hepatic abscess that formed secondary to fish bone penetration by percutaneous transhepatic removal of the foreign body: report of a case. Surg Today 1999; 29:922-926.

2 Yasuda T, Kawamura S, Shimada E, Okumura $S$ : Fish bone penetration of the duodenum extending into the pancreas: report of a case. Surg Today 2010;40:676-678.

3 Gharib SD, Berger DL, Choy G, Huck AE: Case records of the Massachusetts General Hospital. Case 21-2015. A 37-year-old American man living in Vietnam, with fever and bacteremia. N Engl J Med 2015;373:174-183. 